\title{
Hospital-based analysis of eye diseases at Karitas Hospital, Southwest Sumba, 2015
}

\author{
Ratna Sitompul, ${ }^{1}$ Saleha Sungkar ${ }^{2}$ \\ ${ }^{1}$ Department of Ophthalmology, Faculty of Medicine, Universitas Indonesia, Jakarta, Indonesia \\ ${ }^{2}$ Department of Parasitology, Faculty of Medicine, Universitas Indonesia, Jakarta, Indonesia
}

\section{ABSTRACT}

Background: This study aimed to determine the profile of eye diseases at Karitas Hospital in Southwest Sumba during 2015.

Methods: The cross-sectional and descriptive study was conducted by analyzing medical records of 1706 patients who presented with eye complaints at Karitas Hospital, Southwest Sumba, in 2015. Complete medical records were recovered from 1363 patients, who served as subjects for this study.

Results: Thirty-six percent of subjects were elderly ( $>55$ years old) and $9.9 \%$ were children ( $<18$ years old). Female patients comprised $56.4 \%$ of the study population and males $43.6 \%$. Non-infectious eye diseases dominated (89.8\%; $95 \% \mathrm{CI}$ : $88.2 \%$ 91.4\%) compared to infectious diseases (8.2\%; 95\%CI: 6.7\%-9.7\%) and mixed cases (2\%; 95\%CI: $1.3 \%-2.7 \%$ ). Avoidable causes of blindness, cataract (34\%), and refractive error (17.3\%), were mostly found among non-infectious cases, while conjunctivitis $(52.7 \%)$ and keratitis $(17 \%)$ were the most commonly encountered infectious diseases.

Conclusion: Eye diseases at Karitas Hospital in Southwest Sumba mostly comprised non-infectious diseases. The most commonly noted non-infectious diseases were cataracts and refractive errors, while conjunctivitis and keratitis were the most commonly found infectious diseases. Due to the high amount of patients seeking eye care within Southwest Sumba, ophthalmologists and proper equipment are needed at the Karitas Hospital.

Keywords: cataract, conjunctivitis, eye diseases, keratitis, refractive error, underdeveloped districts

pISSN: 0853-1773•eISSN: 2252-8083• https://doi.org/10.13181/mji.v27i3.2686• Med J Indones. 2018;27:213-9

- Received 03 Mar 2018• Accepted 23 Aug 2018

Corresponding author: Ratna Sitompul

ratna_sitompul@yahoo.com

Copyright @ 2018 Authors. This is an open access article distributed under the terms of the Creative Commons Attribution-NonCommercial 4.0 International License (http://creativecommons.org/licenses/by-nc/4.0/), which permits unrestricted non-commercial use, distribution, and reproduction in any medium, provided the original author and source are properly cited. 
It is reported that the province of East Nusa Tenggara (ENT) has the second-highest prevalence of blindness (1\%) in Indonesia. ${ }^{1}$ According to the World Health Organization (WHO), ${ }^{2}$ any prevalence of blindness exceeding $0.5 \%$ is a social concern. As such, the province of ENT has a health problem requiring special attention., ${ }^{3,4}$ The four main causes of blindness in Indonesia are cataracts, glaucomas, uncorrected refractive errors, and degenerative diseases, such as diabetic retinopathy and age macular degeneration. ${ }^{5,6}$

The Southwest Sumba district in ENT is underdeveloped and includes isolated rural populations with difficult access to health care facilities, limited eye care equipment, and adequately trained personnel. Most residents of the district are impoverished, poorly educated, and have no exposure or awareness of key eye health issues. Since the district's sole hospital has no ophthalmologist, the general practitioner and senior ophthalmology-trained nurse perform eye examinations and treatments. The availability of eye treatments are limited; therefore, patients requiring further management are referred to the nearest hospitals with ophthalmologists located in Kupang or Denpasar, requiring additional funding and effort.

Blindness is defined by WHO as visual acuity $<3 / 60$ and low vision is defined as visual acuity of $3 / 60-6 / 18$ in the best-corrected eye. ${ }^{7}$ Blindness and low vision severely impact individuals along with their families and communities. Any conditions leading to the aforementioned visual acuity are classified as causes of blindness. Avoidable causes of blindness are defined as preventable eye conditions leading to blindness and include cataracts, refractive errors, glaucomas, and diabetic retinopathy. Unavoidable causes of blindness include trauma or childhood blindness. Therefore, the prevention of blindness is of paramount public health importance. This can be accomplished by screening for eye diseases by nurses qualified to recognize and refer patients with a risk of blindness for care by ophthalmologists.

The prevalence of avoidable and nonavoidable blindness, in addition to the causes and prevalence of infectious and non-infectious eye diseases, directly inform the mitigation strategy (i.e., qualifications of eye care personnel, appropriate facilities, equipment, and drugs). Therefore, we conducted a survey of eye disease profiles in patients seeking eye care at Karitas Hospital in Southwest Sumba in 2015.

\section{METHODS}

\section{Study location}

This study was done in the district of Southwest Sumba, ENT, Indonesia by obtaining data from the only hospital serving the district, Karitas Hospital (or Charitas of Christian Charity and a government-supported church operated facility) located in the capital city of Tambolaka. Southwest Sumba is an underdeveloped and impoverished district involving poor education and difficult access to health care services. Eye disease diagnoses are based on the patients' history and a simple eye examination conducted by a general practitioner and ophthalmologytrained nurses using a Snellen-chart, penlight, slit lamp, and direct ophthalmoscope.

\section{Data collection}

This descriptive study had a crosssectional design and the data was collected from patients with primary complaints involving eye diseases, The data was obtained from patient medical records from the ophthalmology clinic at Karitas Hospital during 2015. The hospital director approved data collection and publication. Further, ethical approval was obtained from the Faculty of Medicine Universitas Indonesia ethical board (0656/UN2.F1/ETIK/2018). Available data included age, gender, and clinical diagnosis; the total sample was used. Age groups included children $(<18$ years old), young adults $(18-35$ years old), middle-aged adults (36-55 years old), and older adults ( $>55$ years old).

Recorded eye diseases were classified as infections due to microorganisms (infectious), non-infectious, or a mix of both. Mixed diagnoses were considered when patients simultaneously suffered from infectious and non-infectious eye problems in one visit, such as conjunctivitis and cataracts. Simple diagnoses which were able to be diagnosed by trained nurse were collected at the initial encounter while more complex diagnosis, requiring ophthalmologist and supportive examinations at referral hospitals or periodic eye 
Table 1. Distribution of eye diseases based on age group and gender

\begin{tabular}{|c|c|c|c|}
\hline Characteristics & Infection, $\mathrm{n}(\%)$ & Non-infection, n (\%) & Mixed, n (\%) \\
\hline Total & 112 (8.2\%; 95\% CI 6.7\%-9.7\%) & 1,224 (89.8\%; 95\% CI 88.2\%-91.4\%) & 27 (2\%; 95\% CI 1.3\%-2.7\%) \\
\hline \multicolumn{4}{|l|}{ Age group } \\
\hline Children & $29(25.9)$ & $103(8.4)$ & $3(11.1)$ \\
\hline Young adult & $41(36.6)$ & 242 (19.8) & $3(11.1)$ \\
\hline $\begin{array}{l}\text { Middle-aged } \\
\text { adult }\end{array}$ & $24(21.4)$ & 417 (34.1) & $11(40.7)$ \\
\hline Older adult & $18(16.1)$ & $462(37.8)$ & $10(37.0)$ \\
\hline Total & $112(100)$ & $1,224(100)$ & $27(100)$ \\
\hline \multicolumn{4}{|l|}{ Gender } \\
\hline Male & $42(37.5)$ & $536(43.8)$ & $16(59.3)$ \\
\hline Female & $70(62.5)$ & $688(56.2)$ & $11(40.7)$ \\
\hline
\end{tabular}

Table 2. Distribution of eye diseases due to infection based on age group and gender

\begin{tabular}{|c|c|c|c|c|c|c|c|c|c|c|}
\hline Characteristics & 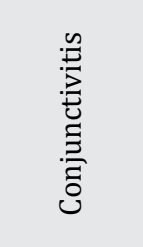 & 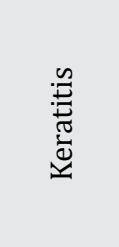 & 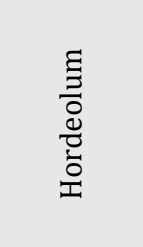 & 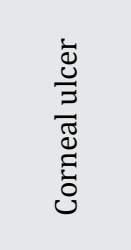 & 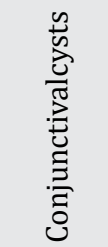 & 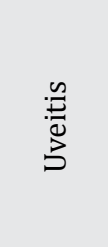 & 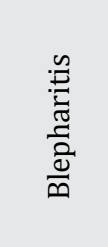 & 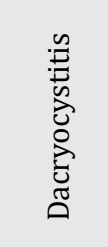 & 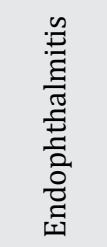 & $\begin{array}{l}\text { Total } \\
\mathrm{n}(\%)\end{array}$ \\
\hline Total (\%) & $59(52.7)$ & $19(17)$ & $15(13.4)$ & $10(8.9)$ & $4(3.6)$ & $2(1.8)$ & $1(0.9)$ & $1(0.9)$ & $1(0.9)$ & \\
\hline \multicolumn{11}{|l|}{ Age group } \\
\hline Children & 9 & 6 & 15 & 4 & 1 & 0 & 1 & 0 & 0 & 29 (25.9) \\
\hline $\begin{array}{l}\text { Young } \\
\text { adults }\end{array}$ & 28 & 5 & 8 & 0 & 1 & 2 & 0 & 0 & 1 & $41(36.6)$ \\
\hline $\begin{array}{l}\text { Middle-aged } \\
\text { adults }\end{array}$ & 9 & 5 & 4 & 5 & 2 & 0 & 0 & 0 & 0 & $24(21.4)$ \\
\hline Older adults & 13 & 3 & 3 & 1 & 0 & 0 & 0 & 1 & 0 & $18(16.1)$ \\
\hline \multicolumn{11}{|l|}{ Gender } \\
\hline Male & 19 & 6 & 5 & 7 & 2 & 2 & 0 & 0 & 1 & $42(37.5)$ \\
\hline Female & 40 & 13 & 10 & 3 & 2 & 0 & 1 & 1 & 0 & $70(62.5)$ \\
\hline
\end{tabular}

examinations from charity events, were recorded during the follow-up period.

Data was then analyzed as percentages using Microsoft Excel including frequency distributions and confidence intervals. Statistical analyses were not performed.

\section{RESULTS}

Among 1706 patients reporting to Karitas Hospital in 2015 with complaints of eye disease, 1363 had complete medical records and were included for analysis in the study. Table 1 shows the demographic properties of the study population being older adults (36\%) and 9.9\% were children. Patients were more likely to be female than male ( $56.4 \%$ vs. $43.6 \%$ ).

Eye diseases were then classified as infectious, non-infectious, or mixed. Noninfectious diseases include dry eye, pterygium, corneal leukoma, non-infectious uveitis, cataract, refractive error, asthenopia, glaucoma, neuritis, trauma, and foreign body. Infectious diseases include blepharitis, dacryocystitis, endophthalmitis, hordeolum, keratitis, 
Table 3. Distribution of non-infectious eye diseases based on age group and gender

\begin{tabular}{|c|c|c|c|c|c|c|c|c|c|c|c|c|c|c|c|}
\hline $\begin{array}{l}\text { Character- } \\
\text { istics }\end{array}$ & 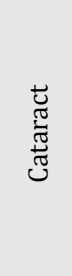 & 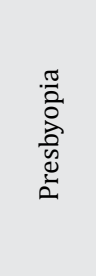 & $\begin{array}{l}\stackrel{0}{\Delta} \\
\stackrel{\Delta}{\Delta}\end{array}$ & 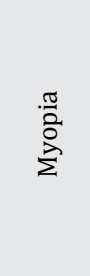 & 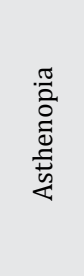 & 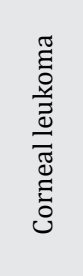 & 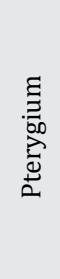 & 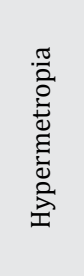 & 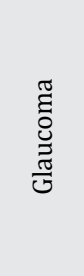 & $\begin{array}{l}: \stackrel{n}{\Xi} \\
\vec{\Xi} \\
z\end{array}$ & 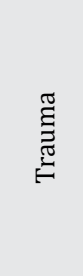 & 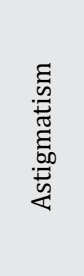 & 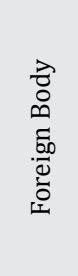 & 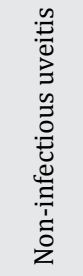 & $\begin{array}{r}\text { Total } \\
\mathrm{n}(\%)\end{array}$ \\
\hline Total n (\%) & $\begin{array}{l}417 \\
(34)\end{array}$ & $\begin{array}{c}212 \\
(17.3)\end{array}$ & $\begin{array}{c}144 \\
(11.8)\end{array}$ & $\begin{array}{c}123 \\
(10.1)\end{array}$ & $\begin{array}{c}72 \\
(5.9)\end{array}$ & $\begin{array}{c}66 \\
(5.4)\end{array}$ & $\begin{array}{l}61 \\
(5)\end{array}$ & $\begin{array}{c}51 \\
(4.2)\end{array}$ & $\begin{array}{c}46 \\
(3.8)\end{array}$ & $\begin{array}{c}43 \\
(3.5)\end{array}$ & $\begin{array}{c}30 \\
(2.5)\end{array}$ & $\begin{array}{c}29 \\
(2.4)\end{array}$ & $\begin{array}{c}27 \\
(2.2)\end{array}$ & $\begin{array}{c}20 \\
(1.6)\end{array}$ & \\
\hline \multicolumn{16}{|l|}{ Age group } \\
\hline Children & 22 & 0 & 7 & 25 & 12 & 12 & 0 & 1 & 1 & 0 & 8 & 2 & 2 & 2 & $\begin{array}{c}94 \\
(6.9)\end{array}$ \\
\hline $\begin{array}{l}\text { Young } \\
\text { adults }\end{array}$ & 16 & 1 & 31 & 51 & 49 & 13 & 16 & 0 & 4 & 16 & 11 & 11 & 13 & 7 & $\begin{array}{c}239 \\
(17.5)\end{array}$ \\
\hline $\begin{array}{l}\text { Middle- } \\
\text { aged } \\
\text { adults }\end{array}$ & 70 & 164 & 53 & 38 & 10 & 23 & 27 & 30 & 12 & 26 & 8 & 14 & 11 & 8 & $\begin{array}{c}494 \\
(36.2)\end{array}$ \\
\hline $\begin{array}{l}\text { Older } \\
\text { adults }\end{array}$ & 309 & 47 & 53 & 9 & 1 & 18 & 18 & 20 & 29 & 1 & 3 & 2 & 1 & 3 & $\begin{array}{c}506 \\
(37.1)\end{array}$ \\
\hline \multicolumn{16}{|l|}{ Gender } \\
\hline Males & 229 & 84 & 48 & 32 & 10 & 32 & 26 & 18 & 16 & 12 & 26 & 6 & 21 & 9 & $\begin{array}{r}569 \\
(41.7)\end{array}$ \\
\hline Females & 188 & 128 & 96 & 91 & 62 & 26 & 35 & 33 & 30 & 31 & 4 & 23 & 6 & 11 & $\begin{array}{c}764 \\
(56.1)\end{array}$ \\
\hline
\end{tabular}

conjunctival cysts, conjunctivitis, corneal ulcer and uveitis. Non-infectious eye diseases comprised almost all of the diagnoses (89.8\%). These were mostly found in females (56.2\%) and older adults (37.8\%). Eye diseases caused by infections occurred in $8.2 \%$ of cases and the remaining $(2 \%)$ were mixed infectious and non-infectious cases, such as conjunctivitis and cataracts or conjunctivitis and refractive errors.

Table 2 shows that the most common infectious eye disease was conjunctivitis $(52.7 \%)$, followed by keratitis $(17 \%)$, hordeolum $(13.4 \%)$, corneal ulcer $(8.9 \%)$, conjunctival cyst (3.6\%), uveitis $(1.8 \%)$, endophthalmitis $(0.9 \%)$, blepharitis $(0.9 \%)$, and dacryocystitis $(0.9 \%)$. These infectious causes occurred more often in females $(62.5 \%)$ than in males $(37.5 \%)$. Young adults comprised most of the infectious cases (36.6\%), followed by children $(25.9 \%)$, middleaged (21.4\%), and older adults (16.1\%). Infectious diseases causing blindness included central corneal opacity, uveitis, and endophthalmitis.
Patients with non-infectious eye diseases sometimes suffered from more than one disease diagnosis. This explains the difference between the number of diagnoses and patients for each diagnosis. Thus, the number of patients with non-infectious eye diseases was 1,224 while the number of cases was 1,343 . Cataracts were the most prevalent cause of blindness comprising $34 \%$ of cases, the majority (74\%) of which comprised older adults, although some children $15.3 \%$ of cases) suffered from traumatic and congenital cataracts as well.

Presbyopia was the second-most prevalent eye condition in this study (17.3\%) and was mostly found in the middle-aged group. Other non-infectious eye diseases were dry eye, pterygium, leukoma, trauma, foreign body, and non-infective uveitis (Table 3). In this study, noninfectious conditions that may lead to blindness were cataracts, glaucomas, refractive errors, diabetic retinopathy, and pterygium. 


\section{DISCUSSION}

Southwest Sumba is an impoverished district with rudimentary eye care facilities. Most residents have low levels of education and tend not to seek medical care until their eye complaints have degraded to unbearable or severe states. The only hospital in the capital of the district (Tambolaka) is located several hours from many of the populated areas it serves. The combination of limited transportation services and relatively high costs create difficulties regarding hospital accessibility. Patients who manage the journey are not likely to return for a follow-up visit due to these difficulties, although there are exceptions in complex and severe cases.

The analysis of medical records from Karitas Hospital demonstrated that noninfectious diseases of the eye were the most prevalent (i.e., refractive error, degenerative diseases, immunology, trauma, metabolic, and neurologic). Refractive error diseases included myopia, hypermetropia, astigmatism, and presbyopia, while degenerative diseases were almost always cataract. These are all causes of avoidable blindness and can be corrected by spectacles or cataract extraction surgery.

In reality, not all patients who suffer from refractive error in Southwest Sumba can afford spectacles. Those who suffer from cataracts often refuse free surgical services since visual impairment with old age is considered acceptable and normal, and providers combat the misunderstanding whereby the eye will be removed during surgery. Another obstacle is the unavailability of an ophthalmologist within the district; referrals for cataract surgery must be transported to other hospitals with ophthalmologists at distant islands; that is, Denpasar or Kupang. Cataract surgery at Karitas Hospital solely occurs when offered by nongovernmental charitable organizations. Another study conducted in an underdeveloped village in Southwest Sumba similarly showed high proportions of non-infectious diseases such as presbyopia $(30.8 \%)$, cataract $(12.8 \%)$, refractive errors $(11.3 \%)$, and pterygium $(10.7 \%){ }^{8}$

Dry eye, a consequence of hyperosmolarity from tear film and inflammation of the ocular surface, comprised $11.4 \%$ of cases in this study. Dry eye is a multifactorial disease and can be etiologically classified into the following two categories: aqueous tear deficiency and loss of fluid due to evaporation. ${ }^{9}$ This study did not differentiate these etiologies due to limited diagnostic facilities and did not record any cases of vitamin A deficiency. ${ }^{10}$

Southwest Sumba is a relatively arid tropical region, and diseases associated with sunlight, dust and wind (e.g., pterygium) commonly occur in Southwest Sumba (5\%). ${ }^{11,12}$ Pterygium was mostly found among middle-aged patients because this group is very often outdoors engaged in agrarian work exposing them to UV light, dust, and wind; risk factors for pterygium formation. Similar results were also found in rural Central India where pterygium was found in $8.47 \%$ of the study population (798 eyes) and was found to be associated with older age, malegender, lower education, lower body height, and higher cylindrical refractive error. ${ }^{13}$

Glaucoma is one of the most prevalent causes of blindness in Indonesia. Blindness due to glaucoma can be prevented through early detection and management. People having glaucoma often do not realize until they experience visual impairment. ${ }^{14}$ At the Karitas Hospital, diagnosis of glaucoma is made upon eye examination and simple supportive examination. The degree of optical nerve damage cannot be monitored which imposes real limitations in evaluating and adjusting its' clinical management.

Poor hygiene in Southwest Sumba likely explains the high prevalence of infectious disease regarding the eyes. People have great difficulty accessing clean water, often walking several kilometers or more to obtain it. Use of potable water is thus limited to drinking and cooking, and unclean water is used for bathing and for washing the hands and face. ${ }^{15}$

Conjunctivitis occurred most often among infectious cases $(52.7 \%)$ with the highest proportion being among young adults. ${ }^{16}$ In reality, many toddlers also suffer from conjunctivitis but parents rarely seek medical care as it is considered normal and self-healing without medications. We have no data concerning conjunctivitis due to trachoma. 
Keratitis occurred in $17 \%$ of subjects. This disease can be caused by viral, bacterial, fungal or parasitic infections not specifically diagnosed in this study. Poor hygiene like that in Southwest Sumba puts residents at risk of these infections. ${ }^{17,18}$ Untreated keratitis may well deteriorate to corneal ulcer and endophthalmitis and may even end in blindness. Additionally, hordeolum, blepharitis, dacryocystitis, and other infections occurred as well; poor hygiene drives these problems. ${ }^{19}$

Despite the established high-risk and prevalence of eye diseases in Southwest Sumba, the district offers only rudimentary eye care services via the tremendous efforts of a trained nurse performing exams using basic equipment. Addressing this obstacle will require the placement or rotation of ophthalmologists, including the tools and equipment they require to offer their specialized services to this at-risk population. Residents need to be better educated about eye health and advocate for examinations and seek care. Advocacy for the provision of free spectacles for children and others, along with social acceptability of cataract surgery, would free many from the burden of avoidable blindness. These conditions not only occur in Southwest Sumba, butalso in otherimpoverished and isolated rural districts all across thousands of islands comprising the 5,500 km Indonesian archipelago. Reaching all of those people with adequate health care services and social awareness is the primary challenge to public health in Indonesia.

In conclusion, among the 1,363 patients coming to Karitas Hospital in Southwest Sumba district, ENT, Indonesia with complete recoverable medical records, 89.8\% (95\% CI: 88.2\%-91.4\%) suffered from non-infectious eye diseases, $8.2 \%$ (95\% CI: 6.7\%-9.7\%) suffered from infectious, and $2 \%$ (95\% CI: $1.3 \%-2.7 \%$ ) suffered from mixtures of both. Cataracts and refractive errors were the two most commonly occurring non-infectious cases, whereas conjunctivitis and keratitis were the most prevalent infectious causes. Due to the high amount of patients seeking eye care in Southwest Sumba, an ophthalmologist along with proper equipment are needed at the Karitas Hospital.

\section{Conflict of Interest}

Saleha Sungkar is one of the editorial board members, but was not involved in the review or decision process of the article. The authors affirm no conflict of interests in this study.

\section{Acknowledgement}

Author would like to thank A.A.G. Oka Wiryanatha, MD, the director of Karitas Hospital and Charles Krisnanda, MD for their support. Author would also like to thank Raph L. Hamers MD PhD from Eijkman Oxford Clinical Research Unit and Indonesia Oxford Clinical Research Laboratory for his valuable inputs in the language aspect of this manuscript.

\section{REFERENCES}

1. Center of data and information Ministry of Health Republic of Indonesia. Situation of visual impairment and blindness. Jakarta: Ministry of Health Republic of Indonesia; 2014.

2. World Health Organization. Global data on visual impairment 2010. Geneva: WHO; 2012.

3. Ministry of Health Republic of Indonesia. Data and information on health of Nusa Tenggara Timur Province [Internet]. 2014 [accessed: 2 Desember 2016]. Available from: http://www.depkes.go.id/ resources/download/pusdatin/kunjungan-kerja/ nusa-tenggara-timur.pdf.

4. Center for Statistics Southwest Sumba District. Civil Registration of Southwest Sumba 2015 [Internet]. 2015 [cited 2 December 2016]. Available from: www. sumbabaratdayakab.bps.go.id.

5. Ministry of Health Republic of Indonesia. Basic health survey 2013. Jakarta: Ministry of Health Republic of Indonesia; 2013.

6. Ministry of Health Republic of Indonesia. Basic health survey 2007. Jakarta: Ministry of Health Republic of Indonesia; 2013.

7. WHO. Vision 2020 the Right to Sight, Global Initiative for the Elimination of Avoidable Blindness: Action Plan 2006-2011. Geneva; WHO:2007.

8. Sitompul R, Lestari YD, Siregar S, Ayudianingrum A, Isfiyanto, Kusumowidagdo G, et al. The burden of ocular diseases in an underdeveloped village in Southwest Sumba, Eastern Indonesia, 2016. Med J Indones. 2017;26(4):277-85.

9. Foster S. Dry eye syndrome. Medscape [online series]. 2016 [cited 6 December 2016]. Downloaded from: http://emedicine.medscape.com/article/1210417overview\#a1.

10. Roh HC, Lee JK, Kim M, Oh JH, Chang MW, Chuck RS, et al. Systemic comorbidities of dry eye syndrome: the Korean national health and nutrition examination survey V, 2010 to 2012. Cornea. 2016;35(2):187-92.

11. Aminlari A, Singh R, Liang D. Management of pterygium. In: Scott IU, Fekrat S, Hofmeister EH, editors. Ophtalmic pearls. American Academy of Ophtalmology; 2010.

12. Wang GQ, Bai ZX, Shi J, Luo S, Chang HF, Sai XY. Prevalence and risk factors for eye diseases, blindness, and low vision in Lhasa, Tibet. Int J Ophthalmol. 2013;6(2):237-41. 
13. Nangia V, Jonas JB, Nair D, Saini N, Nangia P, Panda-Jonas S. Prevalence and associated factors for pterygium in rural agrarian Central India. The Central India and medical study. PloS ONE. 2013;8(12):e82439.

14. Pan CW, Zhao CH, Yu MB, Cun Q, Chen Q, Shen W, et al. Prevalence, types and awareness of glaucoma in a multiethnic population in rural China: the Yunnan minority eye study. Ophtalmic Physiol Opt. 2016;36(6):664-70.

15. Sungkar S, Pohan AP, Ramadani A, Albar N, Azizah F, Nugraha AR, et al. Heavy burden of intestinal parasite infections in Kalena Rongo village, a rural area in South West Sumba, eastern part of Indonesia: a cross sectional study. BMC Public Health. 2015;15:1296.

16. Varma R, Kim JS, Burkemper BS, Wen G, Torres M, Hsu
C, et al. Prevalence and causes of visual impairment and blindness in chinese American adults: the chinese american eye study. JAMA Ophthalmol. 2016;134(7):785-93.

17. Cao J, Yang Y, Yang $\mathrm{W}, \mathrm{Wu} \mathrm{R}, \mathrm{Xiao} \mathrm{X}$, Yuan J, et al. Prevalence of infectious keratitis in Central China. BMC Ophtalmol. 2014;14:43.

18. Singh A, Dwivedi S, Dabral SB, Bihari V, Rastogi AK, Kumar D. Ocular morbidity in the rural areas of Allahabad, India. Nepal J Ophthalmol. 2012;4(7):49-53.

19. Monsudi KF, Saka ES, Azonobi RI. Pattern of eye diseases present at free outreach in rural community in the Northwestern Nigeria. Sudan Medical Monitor. 2015;10(4):113-6. 